\title{
Customer Loyalty in e-Banking: A Structural Equation Modelling (SEM) Approach
}

\author{
Suleiman G. P, Nik Kamariah Nik Mat", Adesiyan O. I, Mohammed A. S, Jamal ALekam \\ Othman Yeop Abdullah Graduate School of Business, Universiti Utara Malaysia, Sintok, 06010, Malaysia
}

\begin{abstract}
Electronic banking, otherwise known as Internet banking (eB) is increasingly popularized in the global market place in facilitating e-commerce. However, the efficiency of these services; with varying degree in connectivity and other factors mostly aimed at cost and speed seems to be rising, especially in the developed and emerging economies. Tools for conducting research over the years have also been changing due to its dynamism in the contemporary e-World (digital age). Customer loyalty has become a benchmark for measuring success in a competitive economic environment where speed in innovation is the survival kit. Loyalty is the endogenous latent variable measured by ten items. The four antecedents of customer loyalty identified and its measurement are - (1) Satisfaction (5 items), (2) Reliability (5 items), (3) Responsiveness (4 items), and (4) Empathy ( 2 items). The data was collected using primary data collection method. 250 questionnaires were distributed to target respondents who are Graduate students (M.Sc and PhD/DBA) and administrative staff of a university in Northern Malaysia. The responses collected are 147 representing 58.5 percent responses rate. The data are analyzed using the structural equation modeling (SEM), specifically AMOS 16 software. The goodness of fit indices of the revised model indicate adequate fit (GFI=.946, RMSEA=.032, RATIO CMIN/DF=1.48, P-VALUE=.230). The study established significance in three direct effects; reliability to customer satisfaction $(\beta=.0 .94, \mathrm{CR}=3.476, \mathrm{P}<.001)$, responsiveness to loyalty $(\beta=0.46, \mathrm{CR}=2.126, \mathrm{P}<.0 .034)$, and satisfaction to loyalty $(\beta=.0 .45, \mathrm{CR}=4.246, \mathrm{P}<.001)$. These findings signify that responsiveness, satisfaction, reliability in bank services ranked high for customer's loyalty in e-banking. It is therefore recommended that banks should evolve strategies that are reliable, responsive and satisfactory in e-banking services to reduce cyber related crime in internet banking amongst other things.
\end{abstract}

Keywords Internet Banking, Customer Loyalty, Satisfaction, Reliability, Bank Products

\section{Introduction}

With the intense nature of competitive atmosphere and the globalization of markets, fundamental changes occurred which have forced many companies to rethink and adapt their business strategies to implementing innovative manage ment techniques and constant search for new philosophies to improve their competitive position. Organizations are putting in place strategies that will create, maintain and retain level of loyalty to their products and increase their organization profit. Banks are not left out in these changes occurring.

Thus the recent increase in business competition and more dynamic market pricing environment have both impacted on effectiveness of marketing strategy in the banking service industry.

As important as effective marketing strategy in determining Bank's success, it is not the only factor[1].

* Corresponding author:

drnikuum@gmail.com (Nik Kamariah Nik Mat)

Published online at http://journal.sapub.org/economics

Copyright (C) 2012 Scientific \& Academic Publishing. All Rights Reserved
Previous researches have proved that customer loyalty is the key driver in a company's profitability thereby underscoring the need to set it as one of the key strategic goals of the company[2],[3]. It has been proved that there is a positive relationship existing between customer loyalty and business performance[4],[5],[6]. These results have triggered many banks into focusing on maintaining long-term relationship with their customers via increasing customer loyalty Jacoby \& Robert[7] believing that the higher the loyalty the better value to their organization and productivity. In fact, customer satisfaction has been proposed as the primary antecedent to customer loyalty[8],[3],[9].

Banks in Malaysia have being trying to improve their customers' level of satisfaction for the purpose of creating a strong preference for their products and hence increase their customers' loyalty. This is the main thrust of this article.

\section{Methodology}

This study evaluated the antecedents of loyalty as shown on research frame work (figure 1). It shows that responsiveness, satisfaction, reliability are direct predictors of customer loyalty while reliability and responsiveness are 
antecedents of customer satisfaction.

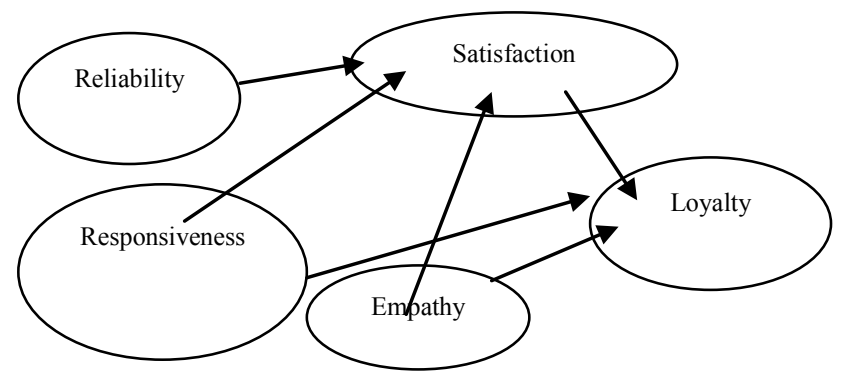

Figure 1. Research Framework

Literature shows that the greater the satisfaction, the greater the customer loyalty[10],[11]. Kheng,Osman, Ramayah \& Mosahab[12] showed that reliability has positive relationships with customer satisfaction. It means that consumer will continue to use the product even though friends, colleagues' exhibit dissatisfaction in the product; the consumer may have no choice[13]. Responsiveness is important in customer loyalty because banks are willing to help users of their products enjoy prompt service[14].

The revised model (figure 2), shows the geometry of the hypothesized model with each variable drawn showing the error terms for each latent variables. Three exogenous variables - reliability (5), responsiveness (4) and empathy (2) with observed variables in the bracket. Empathy showed a negative direct relationship to loyalty: observe that special individual attention is not a factor for customer loyalty to bank services. Two endogenous variables, satisfaction and

loyalty with the subsequent error terms are also shown on figure 2. CFAs are shown indicating model fit for each of the IV/DV. Sampling and instrument 250 questionnaires were distributed to target respondents who are Graduate students (M.Sc and $\mathrm{PhD} / \mathrm{DBA}$ ) and administrative staff of a university in Northern Malaysia. The responses collected are 147 representing 58.5 percent responses rate. The data are analyzed using the structural equation modelling (SEM), specifically AMOS - 16 soft ware.

\section{Literature Review}

\subsection{Introduction}

In this ever dynamic and competitive global business environment, it is not enough to retain customers through good adverts, attractive or window dressing products, but imperative to go extra miles to make these gullible customers loyal to the product(s), while sustainability of such product(s) is (are) ensured. It is on this background that the relevant studies on customer loyalty in e-banking are being reviewed. This is done with the intention to examine a framework relating customer loyalty to antecedents of customer loyalty.

\subsection{The Concept of E-Banking}

Various authors examined conceptual definitions to e-banking. A study in United Kingdom and the Republic of
Ireland respectively on electronic banking, Daniel[15] described it as the information or services provided through the internet by a bank to its product consumers as the need arises. Across the globe adoption of e-baking as compare to the orthodox (offline banking) is on the increase, because of the associated benefits of e-banking.

Table 1. The Operational Definitions of the Dimensions

\begin{tabular}{|c|c|}
\hline Dimension & Definition \\
\hline Reliability & $\begin{array}{c}\text { The product has dependability (safely work } \\
\text { with/use) characteristics and visually good }\end{array}$ \\
\hline Responsiveness & $\begin{array}{c}\text { Readiness to help the consumer in different } \\
\text { circumstances at the time needed }\end{array}$ \\
\hline Empathy & $\begin{array}{c}\text { Individualized attention (emotionally attached) } \\
\text { provided to the product user(s) }\end{array}$ \\
\hline Satisfaction & $\begin{array}{c}\text { Relaxed that the product is safe from past } \\
\text { experience and the firm's service quality } \\
\text { records. }\end{array}$ \\
\hline Loyalty & $\begin{array}{c}\text { Repeat (continuous) patronage (usage) of the } \\
\text { product and recommending (high P.R) of the } \\
\text { product. }\end{array}$ \\
\hline
\end{tabular}

\subsection{Antecedents of Loyalty}

The four antecedents of customer loyalty identified in this study and its measurement are - (1) customer satisfaction (2) reliability (3) responsiveness and (4) empathy. Oliver[3] described customer satisfaction as the consumer's fulfillment response judgment that a product or service feature or the product or service itself provided a pleasurable level of consumption-related fulfillment. Three basic components are identified by Giese \& Cote[16] in customer satisfaction (1) response type- cognitive, affective or cognitive (2) subject of interest and (3) evaluation time- it could be before choice, after choice, after consumption or even at any time.

As the number of e-Banking customers is increasing at an exponential rate, the importance of reliability influencing customer's willingness to engage in online transactions is rising steadily. Kheng,Osman, Ramayah \& Mosahab[12] defined reliability as the ability to perform the promised service dependably and accurately. In most of the studies that relates loyalty (as dependent variable) with customer satisfaction reliability is perceived as an important antecedent in their models[12],[17]. One of the vital variables that will prompt most of the customers to patronize e-Banking product or package is responsiveness, which is defined as willingness or readiness to help customers and provide prompt service. Glaveli Petridou, Liassides \& Spathis,[18] responsiveness is an essential ingredient for bank to attract more customers.

Empathy is defined as caring and individualized attention that the firm provides to its customers[12]. In order to gain and retain customers, the banks need to understand its teeming customers and pay a rapt attention to them. This will in turn ginger them to be loyal to the bank. Butcher, Sparks\& Callaghan[19], friendship between customers and certain service employees has a major impact on the development of customer loyalty. The relationships between the above described factors with regards to customer loyalty 
are expanded further in the following discussion.

\subsection{Relationship between Customer Satisfaction and Loyalty}

Previous literature showed that customer satisfaction contributed to loyalty[20] in a framework of customer satisfaction in a $\mathrm{B} 2 \mathrm{C}$ e-commerce setting for explaining the relationship between customer satisfaction and e-loyalty. The finding of this study supports the existing body of literature[21],[22] on the positive relationship between customer satisfaction and loyalty.

\subsection{Relationship between Reliability and Customer Loyalty}

Reliability is ability to perform the promised service dependably and accurately[12]. As described above it indicates that there is an effect of reliability on customer satisfaction. Nguyen and Leblanc[23], Bellini et al.[24] and Kheng et al[12] proved that there exist a positive relationship between reliability and customer loyalty. However, Zeithaml Berry \& Parasuraman[13] has a contrary findings, they argued that the relationship between reliability and customer satisfaction is negative. They emphasized that a customer may retain is patronage, because he/she has no choice, and not necessary that he/she is pleased with the services being obtained,

\subsection{Relationship between Responsiveness and Customer Loyalty}

According to Glaveli Petridou, Liassides \& Spathis[18] responsiveness is an essential ingredient for bank to attract more customers and to have an enduring long success. In the studies related to e-Banking customer loyalty, there was an empirical irregularity among the researchers - Glaveli et. al., [18] established the positive relationship of responsiveness with customer loyalty. This findings was also corroborated by Jun and Cai,[25]; Diaz \& Ruiz[26] in a similar studies. Khenget[12] in their study discovered that, though there was positive relationship between responsiveness and customer satisfaction but is insignificant.

\subsection{Relationship between Empathy and Customer Loyalty}

Empathy is about caring, customer understanding and individual attention, provided to the customers via electronic channels. Butcher[27], Ehigie[28], Ndubisi[29] \& Kheng et al[12] supported the significant positive relationship that exist between empathy and customer relationship. Develop ment of customer loyalty is a function of the extent of friendship that exists between individual bank employee and customer[19].

\section{Finding}

The study examined the dimensions in studying customer loyalty. Most dimensions, had established significant relatio nships. Empathy has however, showed negative relationship $\mathrm{s}$ to loyalty as shown on figure 2 .

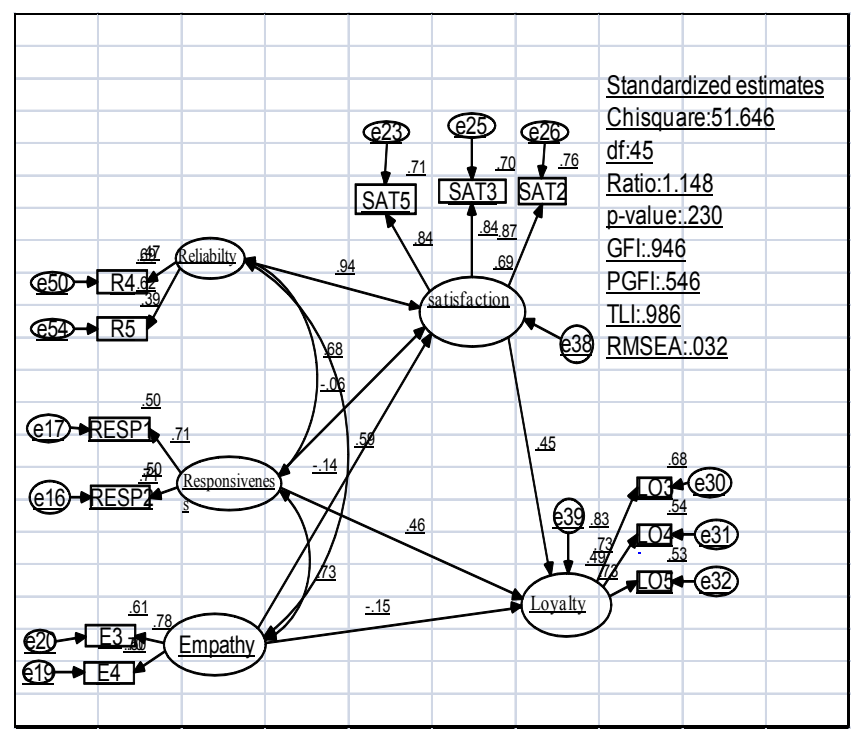

Figure 2. Revised Model

The study established significance in three significant direct effects; reliability to customer satisfaction $(\beta=.0 .94$, $\mathrm{CR}=3.476, \mathrm{P}<.001)$, responsiveness to loyalty $(\beta=0.46$, $\mathrm{CR}=2.126, \mathrm{P}<.0 .034)$, and satisfaction to loyalty $(\beta=.0 .45$, $\mathrm{CR}=4.246, \mathrm{P}<.001)$. The Model fit for all the constructs is shown on figure $2-$ the revised model. Table 2 on the other hand show important decision results - the regression weights which shows the Critical ratio, $\mathrm{P}$ - value as reported earlier.

Regression weights show three significant relationships as stated earlier.

Table 2. Regression Weights (G.No1 - Default Model)

\begin{tabular}{|ccc|cccccc|}
\hline & & & Estimate & S.E. & C.R. & P & Label \\
\hline Satisfaction & $<--$ & Reliability & .938 & .360 & 3.476 & $* * *$ & par_8 \\
Satisfaction & $<--$ & Responsive & -.058 & .224 & -.234 & .815 & par_9 \\
Satisfaction & $<--$ & Empathy & -.142 & .203 & -.734 & .463 & par_10 \\
Loyal & $<--$ & Empathy & -.146 & .198 & -.778 & .436 & par_11 \\
Loyal & $<--$ & Responsive & .458 & .198 & 2.126 & .034 & par_12 \\
& & & & & & & \\
Loyal & $<---$ & Satisfaction & .453 & .108 & 4.246 & $* * *$ & par_13 \\
\hline
\end{tabular}


Table 3. Individual CFA Measurements (Model Fit)

\begin{tabular}{|c|c|c|c|c|c|c|c|}
\hline & CMIN & DF & PVALUE & GFI & AGFI & CFI & RMSEA \\
\hline & 3.879 & 2 & 0.144 & 0.987 & 0.936 & 0.988 & 0.08 \\
\hline Reliability & & & & & & & \\
\hline Responsiveness & 6.513 & 2 & 0.39 & 0.979 & 0.894 & 0.971 & 0.124 \\
\hline & & & & & & & \\
\hline Empathy & 8.941 & 5 & 0.111 & 0.978 & 0.933 & 0.983 & 0.073 \\
\hline Satisfaction & & & & & & & 0.995 \\
\hline
\end{tabular}

\section{Discussion}

This study examined the causal relationships between four antecedents of customer loyalty in the electronic banking, identified in this study and their measurements are - (1) Customer Satisfaction (2) Reliability (3) Responsiveness and (4) Empathy). The conceptual definition to e-banking is information or services provided through the internet by a bank of its products[10].The revised model accomplished model fit and supports three direct effects. Firstly, reliability is a significant positive antecedent of customer satisfaction via loyalty, then responsiveness to loyalty, satisfaction to loyalty. These showed significant relationships. Empathy (individualized attention or captured emotions by service providers), the model fit shows a mixed state, and thus it cannot be a representative for generalizations since studies are divided on a positive and negative lines - for instance empathy in this study. The data used is sourced from one region; the model could not be generalized to the population.

Table 3 , is the individual CFA measurement (Model fit) and shows good fit on individualized outlook from the values. However the RMSEA value for responsiveness is higher $(0.124>0.08)$. The result of SEM indicates $(\beta=.0 .45, \mathrm{CR}=$ 4.246, $\mathrm{P}<.001$ ) that the relationships (customer satisfaction $---\rightarrow$ Loyalty established a significant relationship.

This explains various environments for efficiency in e-banking - that most e-services seems to be efficient is

urban than suburban settings due to disparities in infrastructures. This is a critical area for service providers.

Generally, the complex state of the global economy (especially in electronic related products), with a high degree of cyber crime (example in January 2008 trading loss incident of Kerviel Fraud in Societe Generale case of \$7.2billion in France, see http://en.wikipedia.org, 2012). Users and service providers of such products must established high reliability and are able to build confidence in users of sources of transactions. This is the essence of customer loyalty.

\section{ACKNOWLEDGEMENTS}

We would like to thank Prof Dr. Nik Kamariah Nik Mat,
Sukma Pea and Jamal Mohammed Esmail Alekam for their helpful comments and assistance on an earlier version of this paper.

\section{REFERENCES}

[1] Christopher, L. (2001). Services Marketing (4th ed.). New Jersey: Pearson Education

[2] Reichheld, Frederick F., "Learning from Customer Defections", Harvard Business Review, Volume 74, Number 2, Pages 56-69, 1996.

[3] Oliver, Richard L., "Whence Consumer Loyalty?", Journal of Marketing, Volume 63, Number 4, Pages 33-44, 1999.

[4] Reichheld, Frederick F., and W. Earl Sasser Jr., "Zero defections: Quality comes to services", Harvard Business Review, Volume 68, Number 5, Pages 105-111, 1990.

[5] Reichheld, Frederick F., "Loyalty-based management", Harvard Business Review, Volume 71, Number 2, Pages 64-73, 1993.

[6] Sheth, Jagdish N., and Atul Parvatiyar, "Relationship Marketing in Consumer Markets: Antecedents and Consequences", Journal of the Academy of Marketing Science, Volume 23, Number 4, Pages 255-271, 1995.

[7] Jacoby, Jacob, and Chestnut, Robert W., Brand Loyalty: Measurement and Management, New York Wiley, New York, 1998.

[8] Cronin Jr., J. Joseph, Michael K. Brady, and G. Tomas M. Hult, "Assessing the Effects of Quality, Value, and Customer Satisfaction on Consumer Behavioural Intentions in Service Environments", Journal of Retailing, Volume 76, Number 2, Page 193, 2000

[9] Boonlertvanich, Karin, "A Conceptual Model for the Repurchase Intentions in the Automobile Service. Industry: The Role of Switching Barriers in Satisfaction-Repurchase Intentions Relationship.

[10] Lien-Ti Bei and Yu-Ching Chio, (2001), An interpreted Model for the effects on perceived product, perceived service quality and, and perceived price fairness on consumer satisfaction and loyalty, Journal of consumer satisfaction, dissatisfaction and complaining behavior, 4(1). pp 125-140 
[11] Asuncion J.V., Fichten C.S., Barile M., Fossey M.E. \& Robillard C. (2004) Access to information and instructional technologies in higher education II: practical recommendations for disability service providers. Journal of Postsecondary Education and Disability 17, 134-137.

[12] KhengL. L, Osman M, Ramayah T, Mosahab R, (2010). The Impact of Service Quality on Customer Loyalty: A Study of Banks in Penang, Malaysia, International Journal of Marketing Studies, vol. 2, no 2,pp.57-65.

[13] Zeithaml, V.A, Berry, L.L, and Parasuraman, A.(1996). The behavioural consequences of service quality. Journal of Marketing, Vol. 60, No April, pp.31-46.

[14] David K. Tse, Bennett CK Yim and Kimmy W. Chan, (2008) "Strengthening Customer Loyalty through Intimacy and Passion: Roles of Customer-Firm Affection and Customer-Staff Relations in Services," Journal of Marketing Research. 45(Dec) 741-756.

[15] Daniel, E. (1998).Online banking: winning the majority", Journal of Financial Services Marketing, Vol. 2 No. 3, pp. 259-70.

[16] Giese, J.L. and Cote, J.A, (2000).“Defining consumer satisfaction", Academy of Marketing Science Review (on line).

[17] Asikhia, O, (2011).E-banking Patronage in Nigeria: An exploratory study of Gender Difference. Business Intelligent Journalvol.4 No 2,pp. 345-355

[18] Glaveli, N., Petridou, E., Liassides, C. and Spathis, C. (2006). Bank Service Quality: Evidence from Five Balkan Countries. Managing Service Quality, Vol. 16, No 4,pp. 380-394..

[19] Butcher.B, Sparksand O'Callaghan,(2001)Evaluative and relational influences on service loyalty. International Journal of Service Industry Management, vol12 NO, PP, 310-327.

[20] Floh,A.and Treiblmaier, H, (2006). What is Keeps the E-Banking Customer Loyal? A Multigroup Analysis of the
Moderating Role of Consumer Characteristics on E-Loyalty in the Financial Service Industry. Journal of Electronic Commerce Research, vol. 7 No2 pp.97-110.

[21] Hallowell, R. (1996). The relationship of customer satisfaction, customer loyalty, and profitability: an empirical study, International Journal of Service Industry Management, Vol. 7,No 4, pp. 27-42.

[22] Bowen, J.T and Chen,S.L. (2001).The relationship between customer loyalty and customer satisfaction, International Journal of Contemporary Hospital Management. 13: 213-217.

[23] Nguyen, N, and Leblanc, G (2001).Corporate image and corporate reputation in customers' retention decisions in services, Journal of Retailing and Consumer Services, vol.8 No 4,pp. 227-236.

[24] Bellini, C.G.P, Lunardi, G.L.and Henrique, J.L, (2005). Service quality in banks: Insights from the Brazilian Experience. Journal of Internet Banking and Commerce, vol.10 No3, pp.150-160

[25] Jun, M. and Cai, S. (2001), "The key determinants of internet banking service quality: a content analysis", The International Journal of Bank Marketing, Vol. 19 No. 7, pp. 276-91.

[26] Diaz, A.B.C, and Ruiz, F.J.M, (2002).The consumer's reaction to delays in service, International Journal of Service Industry Management, vol.13 No 2, pp.118-140.

[27] Butcher, K, (2001).Evaluative and relational influences on service loyalty, International Journal of Service Industry Management, vol. 12 No4, pp. 310-327.

[28] Ehigie, B. O, (2006).Correlates of customer loyalty to their bank: a case study in Nigeria. International Journal of Bank Marketing, vol.24 No 7, pp. 494-508.

[29] Ndubisi, N. O. (2006). A structural equation modelling of the antecedents of relationship quality in the Malaysia banking sector Journal of Financial Services Marketing, vol.11 No2, pp.131-141. 